\title{
A personalised approach to prostate cancer screening based on genotyping of risk founder alleles
}

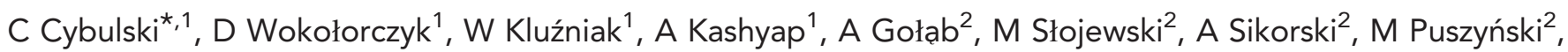
M Soczawa ${ }^{2}$, T Borkowski ${ }^{3}$, A Borkowski ${ }^{3}$, A Antczak $^{4}$, J Przybyła ${ }^{5}$, M Sosnowski $^{5}$, B Małkiewicz $^{6}, \mathrm{R}^{2}$ drojowy $^{6}$, P Domagała ${ }^{7}$, K Piotrowski ${ }^{8}$, J Menkiszak ${ }^{9}$, K Krzystolik ${ }^{10}$, J Gronwald ${ }^{1}$, A Jakubowska ${ }^{1}$, B Górski ${ }^{1}$, T Dębniak ${ }^{1}$, B Masojć ${ }^{1}$, T Huzarski ${ }^{1}$, K R Muir ${ }^{11,12}$, A Lophatananon ${ }^{11,12}$, J Lubiński ${ }^{1}$, S A Narod ${ }^{13}$ and the Polish Hereditary Prostate Cancer Consortium ${ }^{14}$

${ }^{1}$ Department of Genetics and Pathology, International Hereditary Cancer Center, Pomeranian Medical University, Szczecin, Poland; ${ }^{2}$ Clinic of Urology, Pomeranian Medical University, Szczecin, Poland; ${ }^{3}$ Department of Urology, Medical University, Warszawa, Poland; ${ }^{4}$ Chair of Urology, Medical University, Poznan, Poland; ${ }^{5}$ Department of Urology, Medical University of Lodz, Lodz, Poland; ' ${ }^{6}$ epartment of Urology and Urological Oncology, University of Medicine, Wrocław, Poland; ${ }^{7}$ Department of Pathology, Pomeranian Medical University, Szczecin, Poland; ${ }^{8}$ Cytogenetics Unit, Department of Pathology, Pomeranian Medical University, Szczecin, Poland; 'Department of Surgical Gynecology and Gynecological Oncology of Adults and Adolescents, Pomeranian Medical University, Szczecin, Poland; ${ }^{10}$ Chair and Clinic of Ophthalmology, Pomeranian Medical University, Szczecin, Poland; ${ }^{11}$ Warwick Medical School, University of Warwick, Coventry, UK; ${ }^{12}$ Centre for Epidemiology, Institute of Population Health, The Medical School University of Manchester, Manchester, UK and ${ }^{13}$ Centre for Research on Womens Health, Toronto, Ontario, Canada

Background: To evaluate whether genotyping for 18 prostate cancer founder variants is helpful in identifying high-risk individuals and for determining optimal screening regimens.

Methods: A serum PSA level was measured and a digital rectal examination (DRE) was performed on 2907 unaffected men aged 40-90. Three hundred and twenty-three men with an elevated PSA ( $\geqslant 4 \mathrm{ng} \mathrm{ml}^{-1}$ ) or an abnormal DRE underwent a prostate biopsy. All men were genotyped for three founder alleles in BRCA1 (5382insC, 4153delA and C61G), for four alleles in CHEK2 (1100delC, IVS2 + 1G>A, del5395 and 1157T), for one allele in NBS1 (657del5), for one allele in HOXB13 (G84E), and for nine lowrisk single-nucleotide polymorphisms (SNPs).

Results: On the basis of an elevated PSA or an abnormal DRE, prostate cancer was diagnosed in 135 of 2907 men (4.6\%). In men with a CHEK2 missense mutation 1157T, the cancer detection rate among men with an elevated PSA or an abnormal DRE was much higher $(10.2 \%, P=0.0008)$. The cancer detection rate rose with the number of SNP risk genotypes observed from $1.2 \%$ for men with no variant to $8.6 \%$ for men who carried six or more variants $(P=0.04)$. No single variant was helpful on its own in predicting the presence of prostate cancer, however, the combination of all rare mutations and SNPs improved predictive power (area under the curve $=0.59 ; P=0.03$ ).

Conclusion: These results suggest that testing for germline CHEK2 mutations improves the ability to predict the presence of prostate cancer in screened men, however, the clinical utility of incorporating DNA variants in the screening process is marginal.

*Correspondence: Dr C Cybulski; E-mail: cezarycy@sci.pam.szczecin.pl

${ }^{14}$ Other members of the Polish Hereditary Prostate Cancer Consortium are listed in appendix.

Received 14 January 2013; revised 8 April 2013; accepted 9 April 2013; published online 30 May 2013

(C) 2013 Cancer Research UK. All rights reserved 0007-0920/13 
Inherited factors contribute to the risk of prostate cancer. These factors include a positive family history of cancer and a mutation in one of several prostate cancer susceptibility genes (BRCA2, BRCA1, CHEK2, NBS1, HOXB13) (Struewing et al, 1997; Dong et al, 2003; Cybulski et al, 2004; Kote-Jarai et al, 2011; Ewing et al, 2012; Leongamornlert et al, 2012). A number of genome-wide association studies (GWAS) have confirmed over 70 singlenucleotide polymorphisms (SNPs) to be associated with prostate cancer risk (Amundadottir et al, 2006; Al Olama et al, 2009; Eeles et al, 2009; Gudmundsson et al, 2009; Takata et al, 2010; Haiman et al, 2011; Kote-Jarai et al, 2011; Eeles et al, 2013). The odds ratios for the susceptibility alleles and prostate cancer risk range from about 1.5 (for BRCA1) to about 20 (for HOXB13), but the odds ratios for the SNPs are generally much lower (range 1.1-1.6).

It has been proposed that one of the utilities resulting from the GWAS studies should be our ability to categorise men into various levels of prostate cancer risk, based on their genotypes at a number of associated SNPs (Macinnis et al, 2011; Goh et al, 2012). The various categories could in turn be used to define optimum surveillance strategies for men at various levels of risk. In practical terms, surveillance currently consists of annual digital rectal examination and serum prostate-specific antigen (PSA). A personalised approach to screening implies the initiation of screening at different ages, and possibility at different frequencies, depending on the inherent level of risk. In one optimistic scenario, some men might be identified to have a sufficiently low risk of prostate cancer that they might forego screening altogether, or postpone it until later in life.

In Poland, we have identified nine founder alleles in four susceptibility genes (Cybulski et al, 2013; Kluźniak et al, 2013). Three founder alleles are in BRCA1 (5382insC, 4153delA and C61G), four are in CHEK2 (1100delC, IVS2 + IG>A, del5395 and I157T) and one (657del5) is in NBS1. We have also confirmed the recently reported association of prostate cancer with $\operatorname{HOXB13}$, although the prevalence of the G84E risk allele is very low (one in 1000 individuals) (Kluźniak et al, 2013). To measure the impact of genotyping men for these genetic variants on the efficiency of prostate cancer screening, we performed PSA and digital rectal examination (DRE) in 2907 men aged 40-90 in Poland. We sought to evaluate whether or not genotyping of 18 different risk alleles in the Polish population will be helpful for determining screening regimens in men with and without a family history of prostate cancer.

\section{MATERIAL AND METHODS}

Patients. We enrolled 2907 men, ages 40-90, with no history of prostate cancer or other cancer, between 2009 and 2012. Study subjects were derived from two sources. The first series consisted of men who had been seen in the outpatient department of the International Hereditary Cancer Center in Szczecin between 2002 and 2009. From the clinic records, 2476 men with no personal history of prostate cancer were invited by mail to participate. Men were preferentially invited to participate if they had a positive family history of prostate cancer or if they carried a founder mutation in one of the three susceptibility genes. Of the 2476 invitations sent, 877 men (35.4\%) accepted the invitation and consented to participate. Of these, 450 had a positive family history of prostate cancer and 427 had no family history of prostate cancer. Some men had been tested for mutations in BRCA1, CHEK2 and NBS1 (eight alleles). The second series included 2030 men who were part of a population-based survey of 1.5 million residents of West Pomerania, which was designed to identify family cancer clusters in 2002. For the current study, 8410 questionnaires of men were selected, including 2713 questionnaires of men with a family history of prostate cancer and 5688 men (at random) with no family history. The 8410 men were invited by mail to participate in the study. Of these, 2705 men came to the study center for an interview between 2009 and 2011. Of these, 2030 men (74.5\%) accepted the invitation to participate. Eight hundred twenty-eight men had a positive family history and 1202 men had no family history of prostate cancer. A blood sample was taken from all men for PSA level and DNA analyses.

Genotyping. DNA was isolated from 5 to $10 \mathrm{ml}$ of peripheral blood. Nine founder mutations (5382insC, 4153delA, C61G in BRCA1; 1100delC, IVS2 + 1G>A, del5395, I157T in CHEK2; 657 del5 in NBS1, and G84E in HOXB13) were detected as described previously (Cybulski et al, 2006; Cybulski et al, 2011; Kluźniak et al, 2013). In brief, they were detected using ASO-PCR, RFLP-PCR, or TaqMan assays.

We also chose nine SNPs for analysis. These SNPs were selected from a panel of 30 candidate SNPs identified by various GWAS studies between 2006 and 2011 (Amundadottir et al, 2006; Al Olama et al, 2009; Eeles et al, 2009; Gudmundsson et al 2009; Kote-Jarai et al, 2011; Haiman et al, 2011). The 30 candidate SNPs were first analysed for association in a series of 661 unselected prostate cancer cases and 720 controls from Poland; 25 of the 30 SNPs were successfully genotyped. The nine SNPs included here were chosen from the 25 SNPs based on the highest odds ratios and the corresponding $P$-values (Supplementary Table 1). A SNP was chosen, when at least one genotype (homozygous or heterozygous) was associated odds ratio for unselected prostate cancer was 1.4 or higher, or the odds ratio was 0.7 or lower (compared with a common homogenous genotype), and the association was significant with $P<0.05$. For five of nine selected SNPs $P$-value was $<0.01$, and for four of nine selected SNPs the association was significant with $P$-value between 0.01 and 0.04 . The selected SNPs were genotyped using TaqMan assays in the current series of 2907 men undergoing prostate cancer screening. All nine SNPs were successfully genotyped in 2804 of 2907 men (96.5\%).

Study protocol. A serum PSA level was measured for all 2907 men and a DRE was performed on 2878 men by one of the three reference urologists. In the event of an elevated PSA level $\left(\geqslant 4.0 \mathrm{ng} \mathrm{ml}^{-1}\right)$ or an abnormal DRE, the man was invited for a 24 -core prostate biopsy. Cancer was diagnosed if it was present in any of the 24 cores.

Statistical analysis. We wished to study the impact of 18 alleles on the detection of prostate cancer in 2907 men undergoing prostate cancer screening. We estimated the prevalence of detected-prostate cancer in the study sample as a whole (total cancers detected/total subjects) and among subgroups defined by age, family history of prostate cancer (yes/no and number of affected relatives) and by the variant alleles. The nine SNPs were studied individually and in combination. To study these in combination, a SNP count was constructed for each study subject, ranging from zero to nine, depending on the number of abnormal genotypes detected.

Receiver operating characteristics were constructed to estimate the area under the curve (AUC) under various screening protocols. To evaluate the performance of the genetic markers (rare mutations and/or common SNPs) in predicting prostate cancer detected by PSA screening, AUCs were calculated in a group of men with PSA $\geqslant 4 \mathrm{ng} \mathrm{ml}^{-1}(n=204)$; the AUCs were calculated including DRE, the genetic factors alone and both in combination. The analyses were carried out using MedCalc for Windows, version 9.5.0.0 (MedCalc Software, Mariakerke, Belgium).

\section{RESULTS}

We screened 2709 Polish men with serum PSA and DRE (Figure 1). In these, 424 men (14.6\%) had an abnormal PSA test 
or DRE. Three hundred twenty-three of the 424 men (76\%) underwent a trans-rectal 24 core ultrasound-guided biopsy (76 men were biopsied because of abnormal PSA and DRE, 132 men were biopsied because of elevated PSA only, and 115 had biopsy because of positive DRE only). In total, prostate cancer was diagnosed in 135 of the 323 (42\%) men, corresponding to 4.6 cancers detected per 100 men screened using combination of PSA and DRE.

We analysed the effects of age and family history on the prostate cancer detection rate. As expected, age was a strong predictor of prostate cancer (Table 1). The prevalence of prostate cancer rose steeply with age from 0.5 per 100 men aged $40-50$ to 20.5 per 100 for men aged 81-90. A family history of prostate cancer in a firstor second-degree relative was associated with only a modest increase in the cancer detection rate (Table 2). The cancer detection rate rose from $4.0 \%$ in men with no affected relative to $5.4 \%$ in men with a positive family history $(P=0.1)$. The majority of men with a positive family history had only one affected relative
(89\%). Only 22 men (1.7\%) could be considered to come from a prostate cancer family (three or more cases of prostate cancer).

We studied the effect of nine rare mutations of BRCA1, NBS1, CHEK2 and HOXB13 on the prostate cancer detection rate. A total 303 of 2907 men (10.4\%) had a mutation in one of the susceptibility genes (Table 3 ). Of the nine rare mutations, only CHEK2 I157T mutation was associated significantly prostate cancer - prostate cancer was detected in 17 of 166 carriers of the I157T allele (10.2\%) and it was detected in 118 of 2741 non-carriers $(4.3 \%) \quad(\mathrm{OR}=2.5, \quad P=0.0008)$. The other genes were not contributory including the highly penetrant HOXB13.

Among $C H E K 2$ carriers, men in all age groups experienced a cancer detection rate in excess of that of non-carriers (Table 4). Among CHEK2 carriers, the cancer detection rate was higher for men with positive family history than in men with no family history $(12.7 \%$ vs $8.7 \%)$ but this was not statistically significant.

The results of including the nine selected SNPs in the screening evaluation are presented in Table 5. In general, individual

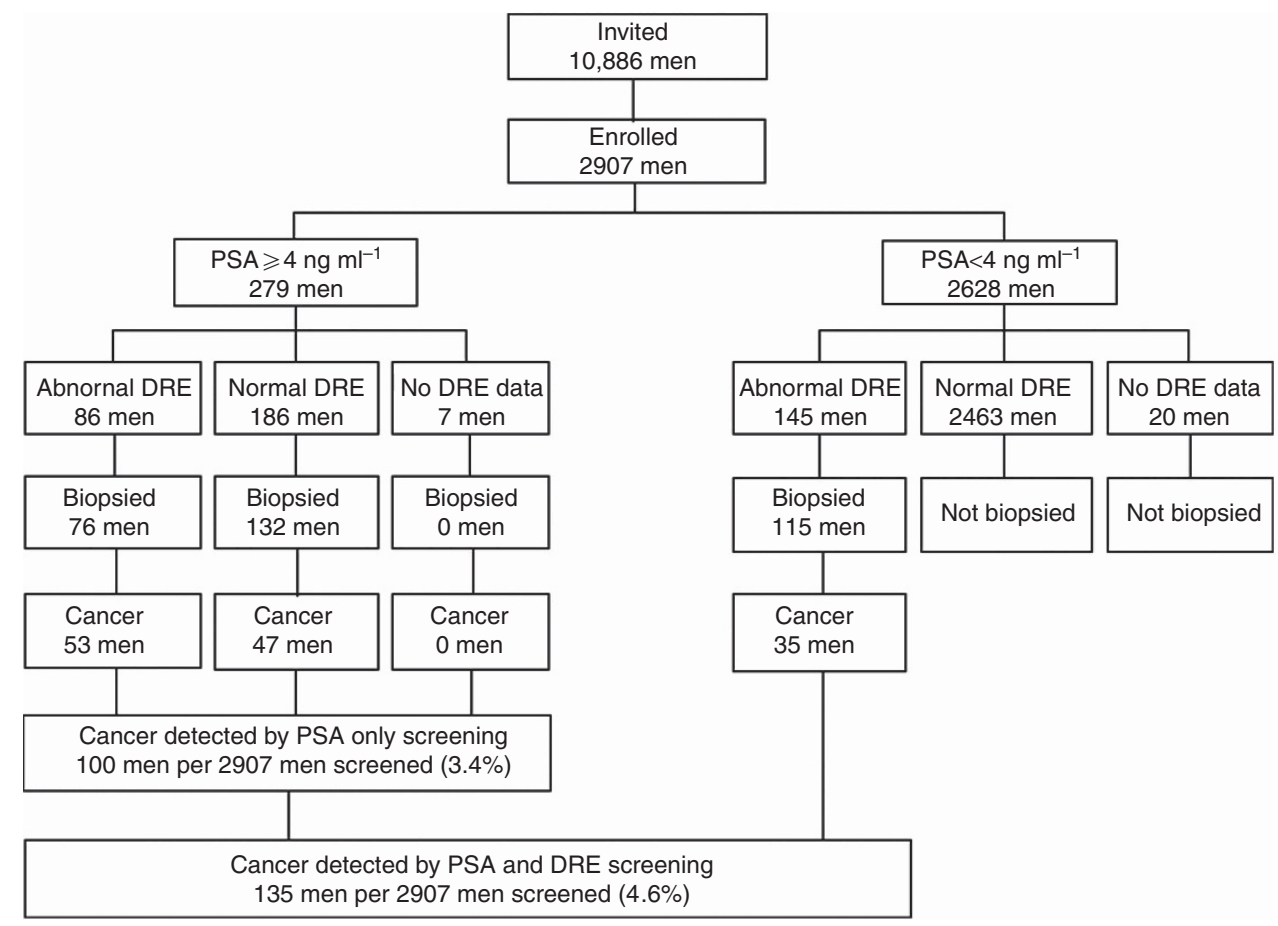

Figure 1. Diagram of the study of the 2907 men who underwent PSA and DRE screening.

Table 1. The frequency of prostate cancer detected in PSA and DRE-based screening and in PSA only screening

No. of cancers detected (cancer prevalence per 1000)

\begin{tabular}{|c|c|c|c|c|c|c|}
\hline Age (years) & No. of men screened & Median PSA & $\begin{array}{c}\text { PSA } \geqslant 4 \mathrm{ng} \mathrm{ml}^{-1} \\
\text { no. (\%) }\end{array}$ & $\begin{array}{l}\text { DRE positive, } \\
\text { no. (\%) }\end{array}$ & PSA only screening & PSA and DRE screening \\
\hline $40-50$ & 182 & 0.75 & $3(1.6)$ & $9(4.9)$ & $0(0)$ & 1 (5) \\
\hline $51-60$ & 1225 & 0.98 & $66(5.4)$ & $67(5.5)$ & $21(17)$ & $28(23)$ \\
\hline $61-70$ & 1023 & 1.31 & $121(11.8)$ & $92(9.0)$ & $50(49)$ & $66(65)$ \\
\hline $71-80$ & 438 & 1.57 & $82(18.7)$ & $54(12.3)$ & $25(57)$ & $32(73)$ \\
\hline $81-90$ & 39 & 1.68 & $7(17.9)$ & $9(23.1)$ & $4(102)$ & $8(205)$ \\
\hline Any & 2907 & 1.11 & $279(9.6)$ & $231(7.9)$ & 100 (34) & $135(46)$ \\
\hline
\end{tabular}


Table 2. Family history of PC and probabilities of cancer risk

No. of cancers detected (cancer prevalence per 1000)

\begin{tabular}{|c|c|c|c|}
\hline $\begin{array}{c}\text { No. of men } \\
\text { screened }\end{array}$ & $\begin{array}{c}\text { PSA only } \\
\text { screening }\end{array}$ & $\begin{array}{c}\text { PSA and DRE } \\
\text { screening }\end{array}$ \\
\hline
\end{tabular}

Family history

\begin{tabular}{|l|l|l|l|}
\hline Negative & 1629 & $50(31)$ & $66(40)$ \\
\hline Positive & 1278 & $50(39)$ & $69(54)$ \\
\hline
\end{tabular}

Number of PCs in relatives

\begin{tabular}{|l|c|c|c|}
\hline 1 & 1136 & $46(40)$ & $62(55)$ \\
\hline 2 & 120 & $3(25)$ & $6(50)$ \\
\hline $3+$ & 22 & $1(45)$ & $1(45)$ \\
\hline
\end{tabular}

Abbreviations: $\mathrm{DRE}=$ digital rectal examination; $\mathrm{PC}=$ prostate cancer; $\mathrm{PSA}=$ prostatespecific antigen.

Table 3. Number of carriers of mutations in four cancer susceptibility genes and probabilities of cancer detected

No. of cancers detected (cancer prevalence per 1000)

\begin{tabular}{|l|c|c|c|}
\hline Gene & $\begin{array}{c}\text { No. of men with } \\
\text { mutation }\end{array}$ & $\begin{array}{c}\text { PSA only } \\
\text { screening }\end{array}$ & $\begin{array}{c}\text { PSA and DRE } \\
\text { screening }\end{array}$ \\
\hline BRCA1 & 57 & $1(18)$ & $2(35)$ \\
\hline CHEK2 all & 217 & $14(64)$ & $19(88)$ \\
\hline $\begin{array}{l}\text { CHEK2 } \\
\text { truncating }\end{array}$ & 50 & $1(20)$ & $2(40)$ \\
\hline $\begin{array}{l}\text { CHEK2 } \\
\text { I157T }\end{array}$ & 166 & $13(78)$ & $17(102)$ \\
\hline NBS1 & 30 & $1(33)$ & $1(33)$ \\
\hline HOXB13 & 5 & $0(0)$ & $0(0)$ \\
\hline $\begin{array}{l}\text { Any } \\
\text { mutation }\end{array}$ & 303 & $16(53)$ & $23(73)$ \\
\hline $\begin{array}{l}\text { No } \\
\text { mutation }\end{array}$ & 2604 & $84(32)$ & $113(43)$ \\
\hline
\end{tabular}

Abbreviations: $\mathrm{DRE}=$ digital rectal examination; $\mathrm{PSA}=$ prostate-specific antigen

genotypes for the SNPs did not predict the presence of prostate cancer (Table 5a). One possible exception was rs16901979. The detection rates in men without and with this variant allele were $4.6 \%$ and $8.4 \%$, respectively $(\mathrm{OR}=1.9 ; P=0.06)$. The probability of prostate cancer being detected increased with the number of variant SNP genotypes observed from $1.2 \%$ for carriers of no risk genotype to $8.6 \%$ for carriers of six or more risk genotypes $(P=0.04)$ (Table 5b). Compared with the cancer detection rate of the population as a whole, men with six or more risk SNP genotypes were observed to be at 1.9 -fold elevated risk $(P=0.3)$. Table 5b includes all nine SNPs and Table $5 c$ includes only the five SNPs used to construct the original Zheng model (Zheng et al, 2008).

To evaluate the global performance of the genetic markers, receiver operating characteristics were constructed to estimate the AUC under various screening protocols. We assessed the performance of the genetic variants (in addition to PSA) in men
Table 4. Probability of prostate cancer detected, by age and family history, among CHEK2 I157T carriers

No. of cancers detected (cancer prevalence per 1000)

\begin{tabular}{|l|c|c|c|}
\hline & $\begin{array}{c}\text { No. of } \\
\text { patients }\end{array}$ & $\begin{array}{c}\text { PSA only } \\
\text { screening }\end{array}$ & $\begin{array}{c}\text { PSA and DRE } \\
\text { screening }\end{array}$ \\
\hline
\end{tabular}

\section{Age interval}

\begin{tabular}{|l|c|c|c|}
\hline All & 166 & $13(78)$ & $17(102)$ \\
\hline $40-50$ & 14 & $0(0)$ & $1(71)$ \\
\hline $51-60$ & 68 & $5(73)$ & $6(88)$ \\
\hline $61-70$ & 61 & $6(98)$ & $7(115)$ \\
\hline $71-80$ & 20 & $2(100)$ & $2(100)$ \\
\hline $80-90$ & 3 & $0(0)$ & $1(333)$ \\
\hline $\begin{array}{l}\text { Positive family } \\
\text { history of PC }\end{array}$ & 63 & $7(111)$ & $8(127)$ \\
\hline $\begin{array}{l}\text { Negative family } \\
\text { history of PC }\end{array}$ & 103 & $6(58)$ & $9(87)$ \\
\hline
\end{tabular}

Abbreviations: $\mathrm{DRE}=$ digital rectal examination; $\mathrm{PC}=$ prostate cancer; $\mathrm{PSA}=$ prostatespecific antigen.

with PSA $\geqslant 4 \mathrm{ng} \mathrm{ml}^{-1}$ who underwent a biopsy (Table 6). The AUC for the rare mutations alone was 0.54, the AUC for the nine SNP model was 0.53 and the AUC for the five SNP model was 0.56 ( $P$-values between 0.2 and 0.4 ). The AUC for the combination of rare mutations and the five SNP model of Zheng was 0.59 and was statistically significant $(P=0.03)$. In addition, we investigated if genetic variants add important information to DRE. The AUC for DRE alone was 0.66, after adding rare mutation and nine SNP data it increased to $0.72(P=0.06)$, after adding rare mutation and five SNP data it increased to 0.72 , and the difference was significant $(P=0.03)$.

Information on Gleason grade was available for all 135 men with cancer. Overall, $43 \%$ of the cases had a Gleason score of 7 or higher. The proportion of men with a high Gleason score was not higher than that for any of the genetically defined subgroups.

\section{DISCUSSION}

Prostate cancer is among the leading causes of morbidity and mortality for cancer in men. In the absence of lifestyle interventions or chemoprevention, prevention is based on early detection. In this study, we sought to evaluate the potential benefit of applying a personalised, gene-based approach to prostate cancer prevention; specifically, we ask if genotyping for 18 susceptibility alleles can improve the performance of the PSA test in a population-based setting. In theory, this could be achieved if we could use the susceptibility alleles, singly or in combination, to define a subgroup of men who harboured the majority of cancers. This was not the case; of the 135 men with prostate cancer, only 22 men had a mutation in one of the known genes and only 5 men carried six or more risk SNP genotypes. Furthermore, the impact of a first-degree relative with prostate cancer on cancer detection was small and was not helpful in classifying men. In contrast, the age of the patient was highly predictive of the presence of cancer and was much more informative than any of the genetically defined categories - the prevalence of prostate cancer rose from 0.5 to $21 \%$ for men in categories of increasing age. 
Table 5. Probabilities of prostate cancer detected by SNPs genotype: (a) for each SNP in isolation; (b) by SNP count - nine SNP model; and (c) by SNP count - five SNP model (Zheng et al, 2008).

(a)

No. of cancers detected (cancer prevalence per 1000)

\begin{tabular}{|l|c|c|c|c|}
\hline SNP & $\begin{array}{c}\text { Risk } \\
\text { genotype }\end{array}$ & $\begin{array}{c}\text { No. of } \\
\text { men }\end{array}$ & $\begin{array}{c}\text { PSA only } \\
\text { screening }\end{array}$ & $\begin{array}{c}\text { PSA and DRE } \\
\text { screening }\end{array}$ \\
\hline rs1859962 & GG & 827 & $29(35)$ & $40(48)$ \\
\hline rs1447295 & AA or AC & 581 & $23(40)$ & $29(50)$ \\
\hline rs6983267 & GG & 661 & $27(41)$ & $34(51)$ \\
\hline rs4430796 a & AA & 865 & $35(40)$ & $46(53)$ \\
\hline rs16901979 a & AA or AC & 143 & $9(63)$ & $12(84)$ \\
\hline rs17021918 & CC & 1215 & $44(36)$ & $58(48)$ \\
\hline rs11649743 & GG & 1832 & $69(38)$ & $95(52)$ \\
\hline rs7679673 & CC & 836 & $28(34)$ & $41(49)$ \\
\hline rs11228565 & AA or AG & 940 & $39(41)$ & $45(48)$ \\
\hline All men & Any & 2907 & $100(34)$ & $135(46)$ \\
\hline
\end{tabular}

(b)

\begin{tabular}{|l|c|c|c|c|}
\hline $\begin{array}{l}\text { No. of risk } \\
\text { genotypes }\end{array}$ & $\begin{array}{c}\text { No. of } \\
\text { men }\end{array}$ & $\%$ & $\begin{array}{c}\text { PSA only } \\
\text { screening }\end{array}$ & $\begin{array}{c}\text { PSA and DRE } \\
\text { screening }\end{array}$ \\
\hline 0 & 85 & 3.0 & $1(12)$ & $1(12)$ \\
\hline 1 & 350 & 12.5 & $10(29)$ & $13(37)$ \\
\hline 2 & 740 & 26.4 & $24(32)$ & $35(47)$ \\
\hline 3 & 832 & 29.7 & $29(35)$ & $43(52)$ \\
\hline 4 & 551 & 19.6 & $22(40)$ & $25(45)$ \\
\hline 5 & 188 & 6.7 & $10(53)$ & $11(58)$ \\
\hline $6-8$ & 58 & 2.1 & $3(52)$ & $5(86)$ \\
\hline
\end{tabular}

No. of cancers detected (cancer prevalence per 1000) (c)

\begin{tabular}{|l|c|c|c|c|}
\hline $\begin{array}{l}\text { No. of risk } \\
\text { genotypes }\end{array}$ & $\begin{array}{c}\text { No. of } \\
\text { men }\end{array}$ & $\%$ & $\begin{array}{c}\text { PSA only } \\
\text { screening }\end{array}$ & $\begin{array}{c}\text { PSA and DRE } \\
\text { screening }\end{array}$ \\
\hline 0 & 298 & 10.6 & $9(30)$ & $13(44)$ \\
\hline 1 & 1084 & 38.6 & $37(34)$ & $51(47)$ \\
\hline 2 & 981 & 35.0 & $27(28)$ & $38(39)$ \\
\hline 3 & 391 & 13.9 & $23(59)$ & $28(72)$ \\
\hline 4 & 49 & 1.7 & $3(61)$ & $3(61)$ \\
\hline 5 & 1 & 0.04 & $0(0)$ & $0(0)$ \\
\hline
\end{tabular}

Abbreviations: $\mathrm{DRE}=$ digital rectal examination; $\mathrm{PSA}=$ prostate-specific antigen; $\mathrm{SNP}=$ single-nucleotide polymorphism.

${ }^{\text {a }}$ SNPs from Zheng model (Zheng et al, 2008)

In this study, the most significant genetic association was seen with the CHEK2 I157T allele. This allele is present in 5\% of the Polish population and in the current study was associated with a relative risk of 2.5 for the detection of prostate cancer. Cancer detection rates in men without and with this allele were $4.0 \%$ and $10.2 \%$, respectively $(\mathrm{OR}=2.5 ; 95 \%$ CI $1.5-4.3 ; P=0.0008)$. Cancer detection rate was $12.7 \%$ for carriers of the $1157 \mathrm{~T}$ allele who reported a positive family history of prostate cancer $(\mathrm{OR}=3.2$; 95\% CI 1.5-6.9; $P=0.004$; compared with non-carriers). Among CHEK2 carriers, men in all age groups experienced a cancer detection rate in excess of that of non-carriers. Previously, in a
Table 6. ROC analysis of the addition of genetic factors (SNPs and/or rare variants) to the prediction of prostate cancer in 208 subjects with $P S A \geqslant 4 n g m l$

\begin{tabular}{|l|l|l|l|l|}
\hline Variables & AUC & s.e. & $95 \% \mathrm{Cl}^{\mathrm{a}}$ & P-value \\
\hline Genetic factors & 0.54 & 0.040 & $0.47-0.61$ & 0,27 \\
\hline Nine rare mutations & 0.56 & 0.040 & $0.49-0.63$ & 0.15 \\
\hline Five SNP model & 0.53 & 0.040 & $0.46-0.60$ & 0.42 \\
\hline Nine SNP model & 0.59 & 0.040 & $0.52-0.66$ & 0.03 \\
\hline $\begin{array}{l}\text { Nine rare mutations } \\
\text { and five SNP model }\end{array}$ & 0.58 & 0.040 & $0.50-0.64$ & 0.06 \\
\hline $\begin{array}{l}\text { Nine rare mutations } \\
\text { and nine SNP model }\end{array}$ & & & & \\
\hline
\end{tabular}

Clinical and genetic factors

\begin{tabular}{|l|c|c|c|c|}
\hline DRE & 0.66 & 0.038 & $0.59-0.72$ & $<0.0001$ \\
\hline $\begin{array}{l}\text { DRE and nine rare } \\
\text { mutations and five SNPs }\end{array}$ & 0.72 & 0.036 & $0.66-0.78$ & $0.03^{*}$ \\
\hline $\begin{array}{l}\text { DRE and nine rare } \\
\text { mutations and nine SNPs }\end{array}$ & 0.72 & 0.036 & $0.65-0.78$ & $0.06^{*}$ \\
\hline
\end{tabular}

Abbreviations: $\mathrm{AUC}=$ area under the curve; $\mathrm{Cl}=$ confidence interval; $\mathrm{DRE}=$ digital rectal examination; $\mathrm{ROC}=$ receiver operating characteristic; $\mathrm{SNP}=$ single-nucleotide polymorphism. Nine rare mutations - a mutation in BRCA1, CHEK2, NBS1 or HOXB13. SNP model - a SNP count was constructed for each study subject, ranging from zero to nine for nine SNP model and ranging from zero to five for five SNP model, depending on the number of abnormal genotypes detected; SNPs included in each model are shown in Table 5. P-values under null hypothesis: true area $=0.5$. ${ }^{*} P$-value from comparison with AUC for DRE.

${ }^{\text {a }}$ Binomial exact.

large association study, we reported an odds ratio of 1.8 (95\% CI 1.5-2.2) associated with this allele for unselected cases and 2.7 (95\% CI 1.7-3.3) for familial cases of prostate cancer (Cybulski et al, 2013). The $I 157 T$ allele also was associated with an odds ratio of 1.5 for unselected prostate cancer and 2.1 for familial prostate cancer in Finland (Seppälä et al, 2003). The CHEK2 I157T mutation has a world-wide distribution. The allele is most common in populations with Northern European origins (Zhang et al, 2008).

We did not find the presence of a BRCA1 mutation to be a predictor of risk, and we do not present data to justify testing men for the three Polish founder alleles (there are no known founder alleles in BRCA2 in Poland). The role of serum PSA screening in $B R C A 1$ and BRCA2 mutation carriers is being evaluated in a large international research study called IMPACT. Preliminary analysis of the data from that support the rationale for continued PSA screening in such men, but do not recommend that all men be screened for mutations (Mitra et al, 2011).

The HOXB13 G84E mutation is associated with a high relative risk of prostate cancer in several countries, including Poland, but the allele is rare $(0.2 \%$ of controls) and was not present in any of the 135 detected cases of prostate cancer. In Sweden, this allele is much more common ( $1.3 \%$ of controls) and may be a significant contributor to the burden of prostate cancer in that country (Karlsson et al, 2012).

On the basis of the receiver operating characteristics, no variant in isolation was helpful in predicting prostate cancer, but in combination, rare mutations and SNPs were associated with modestly elevated AUC of $0.59(P=0.03)$. These results suggest that our selection of genetic variants does not add very much clinically at this stage, and our series the genetic markers do not have clinical utility. However, many more markers have recently become available and therefore a fuller assessment of genetic risk may yet in the future add to existing clinical markers (Eeles et al, 2013). 
Association studies have identified numerous SNPs associated with prostate cancer, but the clinical role of these SNPs in risk management has not been proven. Klein et al, (2012) evaluated 50 previously identified SNPs for predicting prostate cancer in a nested case-control study from a large prospective populationbased cohort (943 cases and 2829 matched controls). They found no clinical benefit in the information gained from the SNPs beyond that of PSA alone (of note, the Malmo cohort includes 28000 men. If this were equivalent to a real clinical situation, it would have meant the genotyping all 28000 men).

There have been a number of studies evaluating the role of prostate cancer screening in men at elevated risk of the disease based on a family history of prostate cancer (McWhorter et al, 1992; Narod et al, 1995; Sartor, 1996; Matikainen et al, 1999; Bunker et al, 2002; Catalona et al, 2002; Mäkinen et al, 2002; Valeri et al, 2002; Uzzo et al, 2003; Horsburgh et al, 2005; Kiemeney et al, 2008). Many authors support screening high-risk men, but the expected benefit of such a programme in a population-based setting has not been formally evaluated previously. In the present study, men were evaluated before screening (i.e., before the discovery of an abnormal PSA or DRE). Most previous studies have focused on men with an abnormal PSA test - in this situation, it is found that the positive predictive values of the PSA test is greater in high-risk groups compared with men at average risk (Catalona et al, 2002), but there has been no subgroup identified for which the risk is sufficiently low that a biopsy can be avoided.

There are several limitations to our study. Our study is based in Poland and the results might not be generalisable to other countries with different distributions of susceptibility alleles. For example, there is no founder allele for BRCA2 in Poland, but these are present in other populations such as Iceland (Thorlacius et al, 1997) and Quebec (Ghadirian et al, 2009). The HOXB13 G48E mutation is much more common in Sweden than in Poland (Karlsson et al, 2012). Our study population was nearly 3000 men, but only 135 were found to have prostate cancer and the number of cases in any genetic subgroup was small. We studied two different populations with different sampling strategies to have adequate representation from both the average-risk and high-risk communities (1278 men had a positive family history of prostate cancer and 1629 men had no family history of prostate cancer). Our criteria for biopsy included a single elevated PSA level $\geqslant 4.0 \mathrm{ng} \mathrm{ml}^{-1}$ or an abnormal DRE. We did not routinely recommend repeat PSA tests or estimate PSA doubling times, because these are not standard screening practices in Poland. We routinely sampled 24 cores, and our sensitivity might have been higher had we taken more core samples or had a less stringent criteria for a biopsy.

Our study does not evaluate the utility of PSA screening per se in reducing mortality from prostate cancer, and the benefit of PSA screening in terms of mortality remains unclear. Three large screening studies are evaluating the role of population screening (Schröder and Bangma, 1997; Prorok et al, 2000; Donovan et al, 2003). The ERSPC study reported a significant reduction in prostate cancer-specific mortality (RR $0.84,95 \%$ CI $0.73-0.95$ ), whereas the PLCO study found no significant benefit (RR 1.15, 95\% CI 0.86-1.54). Pooled data from five randomised controlled trials (including the PLCO and ERSPC) currently demonstrate no significant reduction in prostate cancer-specific and overall mortality (Ilic et al, 2013). The American Cancer Society currently recommends a discussion about PSA screening with men aged $\geqslant 50$ years, or aged $\geqslant 45$ years for African-American men or those with a family history of prostate cancer (Smith et al, 2009). It has been estimated that $84 \%$ of screen-detected cancers will not impact on mortality (McGregor et al, 1998). This may not necessarily be the case for men with germline mutations in the genes studied here. It is noteworthy that the cancers in men with BRCA2 mutations and the NBS1 mutation appear to be particularly aggressive and the benefits of screening for these men may exceed that of the general population (Sigurdsson et al, 1997; Narod et al, 2008; Mitra et al, 2008; Edwards et al, 2010; Thorne et al, 2011; Kote-Jarai et al, 2011; Cybulski et al, 2013). Therefore, men with germline mutations may potentially be at risk of developing highly aggressive prostate cancers. It is important that future studies address these questions.

\section{ACKNOWLEDGEMENTS}

This study was funded by resources for the science of the Polish Ministry of Science and Higher Education as requested research grant PBZ-MNiSW-05/I/2007/02 We thank Daria Zanoza for her support in this study.

\section{REFERENCES}

Al Olama AA, Kote-Jarai Z, Giles GG, Guy M, Morrison J, Severi G, Leongamornlert DA, Tymrakiewicz M, Jhavar S, Saunders E, Hopper JL, Southey MC, Muir KR, English DR, Dearnaley DP, Ardern-Jones AT, Hall AL, O'Brien LT, Wilkinson RA, Sawyer E, Lophatananon A. UK Genetic Prostate Cancer Study Collaborators/British Association of Urological Surgeons' Section of Oncology; UK Prostate testing for cancer and Treatment study (ProtecT Study) Collaborators, Horwich A, Huddart RA, Khoo VS, Parker CC, Woodhouse CJ, Thompson A, Christmas T, Ogden C, Cooper C, Donovan JL, Hamdy FC, Neal DE, Eeles RA, Easton DF (2009) Multiple loci on 8q24 associated with prostate cancer susceptibility. Nat Genet 41: 1058-1060.

Amundadottir LT, Sulem P, Gudmundsson J, Helgason A, Baker A, Agnarsson BA, Sigurdsson A, Benediktsdottir KR, Cazier JB, Sainz J, Jakobsdottir M, Kostic J, Magnusdottir DN, Ghosh S, Agnarsson K, Birgisdottir B, Le Roux L, Olafsdottir A, Blondal T, Andresdottir M, Gretarsdottir OS, Bergthorsson JT, Gudbjartsson D, Gylfason A, Thorleifsson G, Manolescu A, Kristjansson K, Geirsson G, Isaksson H, Douglas J, Johansson JE, Bälter K, Wiklund F, Montie JE, Yu X, Suarez BK, Ober C, Cooney KA, Gronberg H, Catalona WJ, Einarsson GV, Barkardottir RB, Gulcher JR, Kong A, Thorsteinsdottir U, Stefansson K (2006) A common variant associated with prostate cancer in European and African populations. Nat Genet 38: 652-658.

Bunker CH, Patrick AL, Konety BR, Dhir R, Brufsky AM, Vivas CA, Becich MJ, Trump DL, Kuller LH (2002) High prevalence of screeningdetected prostate cancer among Afro-Caribbeans: the Tobago Prostate Cancer Survey. Cancer Epidemiol Biomarkers Prev 11: 726-729.

Catalona WJ, Antenor JA, Roehl KA, Moul JW (2002) Screening for prostate cancer in high risk populations. J Urol 168: 1980-1983.

Cybulski C, Górski B, Debniak T, Gliniewicz B, Mierzejewski M, Masojć B, Jakubowska A, Matyjasik J, Złowocka E, Sikorski A, Narod SA, Lubiński J (2004) NBS1 is a prostate cancer susceptibility gene. Cancer Res 64: 1215-1219.

Cybulski C, Wokołorczyk D, Huzarski T, Byrski T, Gronwald J, Górski B, Debniak T, Masojć B, Jakubowska A, Gliniewicz B, Sikorski A, Stawicka M, Godlewski D, Kwias Z, Antczak A, Krajka K, Lauer W, Sosnowski M, Sikorska-Radek P, Bar K, Klijer R, Zdrojowy R, Małkiewicz B, Borkowski A, Borkowski T, Szwiec M, Narod SA, Lubiński J (2006) A large germline deletion in the Chek2 kinase gene is associated with an increased risk of prostate cancer. J Med Genet 43: 863-866.

Cybulski C, Wokołorczyk D, Jakubowska A, Huzarski T, Byrski T, Gronwald J, Masojć B, Deebniak T, Górski B, Blecharz P, Narod SA, Lubiński J (2011) Risk of breast cancer in women with a CHEK2 mutation with and without a family history of breast cancer. J Clin Oncol 29: 3747-3752.

Cybulski C, Wokołorczyk D, Kluźniak W, Jakubowska A, Górski B, Gronwald J, Huzarski T, Kashyap A, Byrski T, Dębniak T, Gołąb A, Gliniewicz B, Sikorski A, Switała J, Borkowski T, Borkowski A, Antczak A, Wojnar L, Przybyła J, Sosnowski M, Małkiewicz B, Zdrojowy R, SikorskaRadek P, Matych J, Wilkosz J, Różański W, Kiś J, Bar K, Bryniarski P, Paradysz A, Jersak K, Niemirowicz J, Słupski P, Jarzemski P, Skrzypczyk M, Dobruch J, Domagała P, Narod SA, Lubiński J (2013) Polish Hereditary Prostate Cancer Consortium An Inherited NBN Mutation isAssociated with Poor Prognosis Prostate Cancer. Br J Cancer 108: 461-468. 
Dong X, Wang L, Taniguchi K, Wang X, Cunningham JM, McDonnell SK, Qian C, Marks AF, Slager SL, Peterson BJ, Smith DI, Cheville JC, Blute ML, Jacobsen SJ, Schaid DJ, Tindall DJ, Thibodeau SN, Liu W (2003) Mutations in CHEK2 associated with prostate cancer risk. Am J Hum Genet 72: 270-280.

Donovan J, Hamdy F, Neal D, Peters T, Oliver S, Brindle L, Jewell D, Powell P, Gillatt D, Dedman D, Mills N, Smith M, Noble S, Lane A. ProtecT Study Group (2003) Prostate Testing for Cancer and Treatment (ProtecT) feasibility study. Health Technol Assess 7: 1-88.

Edwards SM, Evans DG, Hope Q, Norman AR, Barbachano Y, Bullock S, Kote-Jarai Z, Meitz J, Falconer A, Osin P, Fisher C, Guy M, Jhavar SG, Hall AL, O'Brien LT, Gehr-Swain BN, Wilkinson RA, Forrest MS, Dearnaley DP, Ardern-Jones AT, Page EC, Easton DF, Eeles RA. UK Genetic Prostate Cancer Study Collaborators and BAUS Section of Oncology (2010) Prostate cancer in BRCA2 germline mutation carriers is associated with poorer prognosis. Br J Cancer 103: 918-924.

Eeles RA, Kote-Jarai Z, AlOlama AA, Giles GG, Guy M, Severi G, Muir K, Hopper JL, Henderson BE, Haiman CA, Schleutker J, Hamdy FC, Neal DE, Donovan JL, Stanford JL, Ostrander EA, Ingles SA, John EM, Thibodeau SN, Schaid D, Park JY, Spurdle A, Clements J, Dickinson JL, Maier C, Vogel W, Dörk T, Rebbeck TR, Cooney KA, Cannon-Albright L, Chappuis PO, Hutter P, Zeegers M, Kaneva R, Zhang HW, Lu YJ, Foulkes WD, English DR, Leongamornlert DA, Tymrakiewicz M, Morrison J, Ardern-Jones AT, Hall AL, O'Brien LT, Wilkinson RA, Saunders EJ, Page EC, Sawyer EJ, Edwards SM, Dearnaley DP, Horwich A, Huddart RA, Khoo VS, Parker CC, Van As N, Woodhouse CJ, Thompson A, Christmas T, Ogden C, Cooper CS, Southey MC, Lophatananon A, Liu JF, Kolonel LN, Le Marchand L, Wahlfors T, Tammela TL, Auvinen A, Lewis SJ, Cox A, FitzGerald LM, Koopmeiners JS, Karyadi DM, Kwon EM, Stern MC, Corral R, Joshi AD, Shahabi A, McDonnell SK, Sellers TA, Pow-Sang J, Chambers S, Aitken J, Gardiner RA, Batra J, Kedda MA, Lose F, Polanowski A, Patterson B, Serth J, Meyer A, Luedeke M, Stefflova K, Ray AM, Lange EM, Farnham J, Khan H, Slavov C, Mitkova A, Cao G. UK Genetic Prostate Cancer Study Collaborators/British Association of Urological Surgeons' Section of Oncology; UK ProtecT Study Collaborators; PRACTICAL ConsortiumEaston DF (2009) Identification of seven new prostate cancer susceptibility loci through a genome-wide association study. Nat Genet 41: 1116-1121.

Eeles RA, Olama AA, Benlloch S, Saunders EJ, Leongamornlert DA, Tymrakiewicz M, Ghoussaini M, Luccarini C, Dennis J, Jugurnauth-Little S, Dadaev T, Neal DE, Hamdy FC, Donovan JL, Muir K, Giles GG, Severi G, Wiklund F, Gronberg H, Haiman CA, Schumacher F, Henderson BE, Le Marchand L, Lindstrom S, Kraft P, Hunter DJ, Gapstur S, Chanock SJ, Berndt SI, Albanes D, Andriole G, Schleutker J, Weischer M, Canzian F, Riboli E, Key TJ, Travis RC, Campa D, Ingles SA, John EM, Hayes RB, Pharoah PD, Pashayan N, Khaw KT, Stanford JL, Ostrander EA, Signorello LB, Thibodeau SN, Schaid D, Maier C, Vogel W, Kibel AS, Cybulski C, Lubinski J, Cannon-Albright L, Brenner H, Park JY, Kaneva R, Batra J, Spurdle AB, Clements JA, Teixeira MR, Dicks E, Lee A, Dunning AM, Baynes C, Conroy D, Maranian MJ, Ahmed S, Govindasami K, Guy M, Wilkinson RA, Sawyer EJ, Morgan A, Dearnaley DP, Horwich A, Huddart RA, Khoo VS, Parker CC, Van As NJ, Woodhouse CJ, Thompson A, Dudderidge T, Ogden C, Cooper CS, Lophatananon A, Cox A, Southey MC, Hopper JL, English DR, Aly M, Adolfsson J, Xu J, Zheng SL, Yeager M, Kaaks R, Diver WR, Gaudet MM, Stern MC, Corral R, Joshi AD, Shahabi A, Wahlfors T, Tammela TL, Auvinen A, Virtamo J, Klarskov P, Nordestgaard BG, Røder MA, Nielsen SF, Bojesen SE, Siddiq A, Fitzgerald LM, Kolb S, Kwon EM, Karyadi DM, Blot WJ, Zheng W, Cai Q, McDonnell SK, Rinckleb AE, Drake B, Colditz G, Wokolorczyk D, Stephenson RA, Teerlink C, Muller H, Rothenbacher D, Sellers TA, Lin HY, Slavov C, Mitev V, Lose F, Srinivasan S, Maia S, Paulo P, Lange E, Cooney KA, Antoniou AC, Vincent D, Bacot F, Tessier DC. COGS-Cancer Research UK GWAS-ELLIPSE (part of GAME-ON) Initiative; stralian Prostate Cancer Bioresource; UK Genetic Prostate Cancer Study Collaborators/British Association of Urological Surgeons' Section of Oncology; UK ProtecT (Prostate testing for cancer and Treatment) Study Collaborators; PRACTICAL (Prostate Cancer Association Group to Investigate Cancer-Associated Alterations in the Genome) ConsortiumKote-Jarai Z, Easton DF (2013) Identification of 23 new prostate cancer susceptibility loci using the iCOGS custom genotyping array. Nat Genet 45: 385-391.

Ewing CM, Ray AM, Lange EM, Zuhlke KA, Robbins CM, Tembe WD, Wiley KE, Isaacs SD, Johng D, Wang Y, Bizon C, Yan G, Gielzak M,
Partin AW, Shanmugam V, Izatt T, Sinari S, Craig DW, Zheng SL, Walsh PC, Montie JE, Xu J, Carpten JD, Isaacs WB, Cooney KA (2012) Germline mutations in HOXB13 and prostate-cancer risk. N Engl J Med 366: 141-149.

Ghadirian P, Robidoux A, Zhang P, Royer R, Akbari M, Zhang S, Fafard E, Costa M, Martin G, Potvin C, Patocskai E, Larouche N, Younan R, Nassif E, Giroux S, Narod SA, Rousseau F, Foulkes WD (2009) The contribution of founder mutations to early onset breast cancser in FrenchCanadian women. Clin Genet 76: 421-426.

Goh CL, Schumacher FR, Easton D, Muir K, Henderson B, Kote-Jarai Z, Eeles RA (2012) Genetic variants associated with predisposition to prostate cancer and potential clinical implications. J Intern Med 271: 353-365.

Gudmundsson J, Sulem P, Gudbjartsson DF, Blondal T, Gylfason A, Agnarsson BA, Benediktsdottir KR, Magnusdottir DN, Orlygsdottir G, Jakobsdottir M, Stacey SN, Sigurdsson A, Wahlfors T, Tammela T, Breyer JP, McReynolds KM, Bradley KM, Saez B, Godino J, Navarrete S, Fuertes F, Murillo L, Polo E, Aben KK, van Oort IM, Suarez BK, Helfand BT, Kan D, Zanon C, Frigge ML, Kristjansson K, Gulcher JR, Einarsson GV, Jonsson E, Catalona WJ, Mayordomo JI, Kiemeney LA, Smith JR, Schleutker J, Barkardottir RB, Kong A, Thorsteinsdottir U, Rafnar T, Stefansson K (2009) Genome-wide association and replication studies identify four variants associated with prostate cancer susceptibility. Nat Genet 41: 1122-1126.

Haiman CA, Chen GK, Blot WJ, Strom SS, Berndt SI, Kittles RA, Rybicki BA, Isaacs WB, Ingles SA, Stanford JL, Diver WR, Witte JS, Hsing AW, Nemesure B, Rebbeck TR, Cooney KA, Xu J, Kibel AS, Hu JJ, John EM, Gueye SM, Watya S, Signorello LB, Hayes RB, Wang Z, Yeboah E, Tettey Y, Cai Q, Kolb S, Ostrander EA, Zeigler-Johnson C, Yamamura Y, Neslund-Dudas C, Haslag-Minoff J, Wu W, Thomas V, Allen GO, Murphy A, Chang BL, Zheng SL, Leske MC, Wu SY, Ray AM, Hennis AJ, Thun MJ, Carpten J, Casey G, Carter EN, Duarte ER, Xia LY, Sheng X, Wan P, Pooler LC, Cheng I, Monroe KR, Schumacher F, Le Marchand L, Kolonel LN, Chanock SJ, Van Den Berg D, Stram DO, Henderson BE (2011) Genome-wide association study of prostate cancer in men of African ancestry identifies a susceptibility locus at 17q21. Nat Genet 43: 570-573.

Horsburgh S, Matthew A, Bristow R, Trachtenberg J (2005) Male BRCA1 and BRCA2 mutation carriers: a pilot study investigating medical characteristics of patients participating in a prostate cancer prevention clinic. Prostate 65: 124-129.

Ilic D, Neuberger MM, Djulbegovic M, Dahm P (2013) Screening for prostate cancer. Cochrane Database Syst Rev 1: CD004720.

Karlsson R, Aly M, Clements M, Zheng L, Adolfsson J, Xu J, Grönberg H, Wiklund F (2012) A population-based assessment of germline HOXB13 G84E mutation and prostate cancer risk. Eur Urol, http://dx.doi.org/ 10.1016/j.eururo.2012.07.027.

Kiemeney LA, Broeders MJ, Pelger M, Kil PJ, Schröder FH, Witjes JA, Vasen HF (2008) Screening for prostate cancer in Dutch hereditary prostate cancer families. Int J Cancer 122: 871-876.

Klein RJ, Hallden C, Gupta A, Savage CJ, Dahlin A, Bjartell A, Manjer J, Scardino PT, Ulmert D, Wallström P, Vickers AJ, Lilja H (2012) Evaluation of multiple risk-associated single nucleotide polymorphisms versus prostate-specific antigen at baseline to predict prostate cancer in unscreened men. Eur Urol 61: 471-477.

Kluźniak W, Wokołorczyk D, Kashyap A, Jakubowska A, Gronwald J, Huzarski T, Byrski T, Dębniak T, Gołąb A, Gliniewicz B, Sikorski A, Switała J, Borkowski T, Borkowski A, Antczak A, Wojnar L, Przybyła J, Sosnowski M, Małkiewicz B, Zdrojowy R, Sikorska-Radek P, Matych J, Wilkosz J, Różański W, Kiś J, Bar K, Bryniarski P, Paradysz A, Jersak K, Niemirowicz J, Słupski P, Jarzemski P, Skrzypczyk M, Dobruch J, Domagała P, Akbari MR, Lubiński J, Narod SA, Cybulski C. Polish Hereditary Prostate Cancer Consortium (2013) The G84E mutation in the HOXB13 gene is associated with an increased risk of prostate cancer in Poland. Prostate 73: 542-548.

Kote-Jarai Z, Leongamornlert D, Saunders E, Tymrakiewicz M, Castro E, Mahmud N, Guy M, Edwards S, O’Brien L, Sawyer E, Hall A, Wilkinson R, Dadaev T, Goh C, Easton D. UKGPCS CollaboratorsGoldgar D, Eeles R (2011) BRCA2 is a moderate penetrance gene contributing to young-onset prostate cancer: implications for genetic testing in prostate cancer patients. $\mathrm{Br}$ J Cancer 105: 1230-1234.

Kote-Jarai Z, Olama AA, Giles GG, Severi G, Schleutker J, Weischer M, Campa D, Riboli E, Key T, Gronberg H, Hunter DJ, Kraft P, Thun MJ, 
Ingles S, Chanock S, Albanes D, Hayes RB, Neal DE, Hamdy FC, Donovan JL, Pharoah P, Schumacher F, Henderson BE, Stanford JL, Ostrander EA, Sorensen KD, Dörk T, Andriole G, Dickinson JL, Cybulski C, Lubinski J, Spurdle A, Clements JA, Chambers S, Aitken J, Gardiner RA, Thibodeau SN, Schaid D, John EM, Maier C, Vogel W, Cooney KA, Park JY, Cannon-Albright L, Brenner H, Habuchi T, Zhang HW, Lu YJ, Kaneva R, Muir K, Benlloch S, Leongamornlert DA, Saunders EJ, Tymrakiewicz M, Mahmud N, Guy M, O'Brien LT, Wilkinson RA, Hall AL, Sawyer EJ, Dadaev T, Morrison J, Dearnaley DP, Horwich A, Huddart RA, Khoo VS, Parker CC, Van As N, Woodhouse CJ, Thompson A, Christmas T, Ogden C, Cooper CS, Lophatonanon A, Southey MC, Hopper JL, English DR, Wahlfors T, Tammela TL, Klarskov P, Nordestgaard BG, Røder MA, Tybjærg-Hansen A, Bojesen SE, Travis R, Canzian F, Kaaks R, Wiklund F, Aly M, Lindstrom S, Diver WR, Gapstur S, Stern MC, Corral R, Virtamo J, Cox A, Haiman CA, Le Marchand L, Fitzgerald L, Kolb S, Kwon EM, Karyadi DM, Orntoft TF, Borre M, Meyer A, Serth J, Yeager M, Berndt SI, Marthick JR, Patterson B, Wokolorczyk D, Batra J, Lose F, McDonnell SK, Joshi AD, Shahabi A, Rinckleb AE, Ray A, Sellers TA, Lin HY, Stephenson RA, Farnham J, Muller H, Rothenbacher D, Tsuchiya N, Narita S, Cao GW, Slavov C, Mitev V, Easton DF, Eeles RA. UK Genetic Prostate Cancer Study Collaborators/British Association of Urological Surgeons' Section of Oncology; UK ProtecT Study Collaborators, The Australian Prostate Cancer BioResource, PRACTICAL Consortium (2011) Seven prostate cancer susceptibility loci identified by a multi-stage genome-wide association study. Nat Genet 43: 785-791.

Leongamornlert D, Mahmud N, Tymrakiewicz M, Saunders E, Dadaev T, Castro E, Goh C, Govindasami K, Guy M, O’Brien L, Sawyer E, Hall A, Wilkinson R, Easton D. UKGPCS CollaboratorsGoldgar D, Eeles R, Kote-Jarai Z (2012) Germline BRCA1 mutations increase prostate cancer risk. Br J Cancer 106: 1697-1701.

Macinnis RJ, Antoniou AC, Eeles RA, Severi G, Al Olama AA, McGuffog L, Kote-Jarai Z, Guy M, O’Brien LT, Hall AL, Wilkinson RA, Sawyer E, Ardern-Jones AT, Dearnaley DP, Horwich A, Khoo VS, Parker CC, Huddart RA, Van As N, McCredie MR, English DR, Giles GG, Hopper JL, Easton DF (2011) A risk prediction algorithm based on family history and common genetic variants: application to prostate cancer with potential clinical impact. Genet Epidemiol 35: 549-556.

Matikainen MP, Schleutker J, Morsky P, Kallioniemi OP, Tammela TL (1999) Detection of subclinical cancers by prostate-specific antigen screening in asymptomatic men from high-risk prostate cancer families. Clin Cancer Res 5: 1275-1279.

McGregor M, Hanley JA, Boivin JF, McLean RG (1998) Screening for prostate cancer: estimating the magnitude of overdetection. CMAJ 159: 1368-1372.

McWhorter WP, Hernandez AD, Meikle AW, Terreros DA, Smith Jr JA, Skolnick MH, Cannon-Albright LA, Eyre HJ (1992) A screening study of prostate cancer in high risk families. J Urol 148: 826-828.

Mitra A, Fisher C, Foster CS, Jameson C, Barbachanno Y, Bartlett J, Bancroft E, Doherty R, Kote-Jarai Z, Peock S, Easton D. IMPACT and EMBRACE CollaboratorsEeles R (2008) Prostate cancer in male BRCA1 and BRCA2 mutation carriers has a more aggressive phenotype. $\mathrm{Br} J$ Cancer $\mathbf{9 8}$ : 502-507.

Mitra AV, Bancroft EK, Barbachano Y, Page EC, Foster CS, Jameson C, Mitchell G, Lindeman GJ, Stapleton A, Suthers G, Evans DG, Cruger D, Blanco I, Mercer C, Kirk J, Maehle L, Hodgson S, Walker L, Izatt L, Douglas F, Tucker K, Dorkins H, Clowes V, Male A, Donaldson A, Brewer C, Doherty R, Bulman B, Osther PJ, Salinas M, Eccles D, Axcrona K, Jobson I, Newcombe B, Cybulski C, Rubinstein WS, Buys S, Townshend S, Friedman E, Domchek S, Ramon Y, Cajal T, Spigelman A, Teo SH, Nicolai N, Aaronson N, Ardern-Jones A, Bangma C, Dearnaley D, Eyfjord J, Falconer A, Grönberg H, Hamdy F, Johannsson O, Khoo V, Kote-Jarai Z, Lilja H, Lubinski J, Melia J, Moynihan C, Peock S, Rennert G, Schröder F, Sibley P, Suri M, Wilson P, Bignon YJ, Strom S, Tischkowitz M, Liljegren A, Ilencikova D, Abele A, Kyriacou K, van Asperen C, Kiemeney L. IMPACT Study CollaboratorsEaston DF, Eeles RA (2011) Targeted prostate cancer screening in men with mutations in BRCA1 and BRCA2 detects aggressive prostate cancer: preliminary analysis of the results of the IMPACT study. BJU Int 107: 28-39.

Mäkinen T, Tammela TL, Stenman UH, Määttänen L, Rannikko S, Aro J, Juusela H, Hakama M, Auvinen A (2002) Family history and prostate cancer screening with prostate-specific antigen. J Clin Oncol 20: 2658-2663.
Narod SA, Dupont A, Cusan L, Diamond P, Gomez JL, Suburu R, Labrie F (1995) The impact of family history on early detection of prostate cancer. Nat Med 1: 99-101.

Narod SA, Neuhausen S, Vichodez G, Armel S, Lynch HT, Ghadirian P, Cummings S, Olopade O, Stoppa-Lyonnet D, Couch F, Wagner T, Warner E, Foulkes WD, Saal H, Weitzel J, Tulman A, Poll A, Nam R, Sun P. Hereditary Breast Cancer Study GroupDanquah J, Domchek S, Tung N, Ainsworth P, Horsman D, Kim-Sing C, Maugard C, Eisen A, Daly M, McKinnon W, Wood M, Isaacs C, Gilchrist D, Karlan B, Nedelcu R, Meschino W, Garber J, Pasini B, Manoukian S, Bellati C (2008) Rapid progression of prostate cancer in men with a BRCA2 mutation. Br J Cancer 99: 371-374.

Prorok PC, Andriole GL, Bresalier RS, Buys SS, Chia D, Crawford ED, Fogel R, Gelmann EP, Gilbert F, Hasson MA, Hayes RB, Johnson CC, Mandel JS, Oberman A, O'Brien B, Oken MM, Rafla S, Reding D, Rutt W, Weissfeld JL, Yokochi L, Gohagan JK. Prostate, Lung, Colorectal and Ovarian Cancer Screening Trial Project Team (2000) Design of the the prostate, lung, colorectal and ovarian (PLCO) cancer screening trial. Control Clin Trials 21: 273-309.

Sartor O (1996) Early detection of prostate cancer in African-American men with an increased familial risk of disease. J La State Med Soc 148: 179-185.

Schröder FH, Bangma CH (1997) The European randomized study of screening for prostate cancer (ERSPC). Br J Urol 79: 68-71.

Seppälä EH, Ikonen T, Mononen N, Autio V, Rökman A, Matikainen MP, Tammela TL, Schleutker J (2003) CHEK2 variants associate with hereditary prostate cancer. Br J Cancer 89: 1966-1970.

Sigurdsson S, Thorlacius S, Tomasson J, Tryggvadottir L, Benediktsdottir K, Eyfjörd JE, Jonsson E (1997) BRCA2 mutation in Icelandic prostate cancer patients. J Mol Med 75: 758-761.

Smith RA, Cokkinides V, Brawley OW (2009) Cancer screening in the United States, 2009: a review of current American Cancer Society guidelines and issues in cancer screening. CA Cancer J Clin 59: $27-41$.

Struewing JP, Hartge P, Wacholder S, Baker SM, Berlin M, McAdams M, Timmerman MM, Brody LC, Tucker MA (1997) The risk of cancer associated with specific mutations of BRCA1 and BRCA2 among Ashkenazi Jews. N Engl J Med 336: 1401-1408.

Takata R, Akamatsu S, Kubo M, Takahashi A, Hosono N, Kawaguchi T, Tsunoda T, Inazawa J, Kamatani N, Ogawa O, Fujioka T, Nakamura Y, Nakagawa H (2010) Genome-wide association study identifies five new susceptibility loci for prostate cancer in the Japanese population. Nat Genet 42: 751-754.

Thorlacius S, Sigurdsson S, Bjarnadottir H, Olafsdottir G, Jonasson JG, Tryggvadottir L, Tulinius H, Eyfjörd JE (1997) Study of a single BRCA2 mutation with a high carrier frequency in a small population. Am J Hum Genet 60: 1079-1084.

Thorne H, Willems AJ, Niedermayr E, Hoh IM, Li J, Clouston D, Mitchell G, Fox S, Hopper JL. Kathleen Cunningham Consortium for Research in Familial Breast Cancer ConsortiumBolton D (2011) Decreased prostate cancer-specific survival of men with BRCA2 mutations from multiple breast cancer families. Cancer Prev Res 4: 1002-1010.

Uzzo RG, Pinover WH, Horwitz EM, Parlanti A, Mazzoni S, Raysor S, Mirchandani I, Greenberg RE, Pollack A, Hanks GE, Watkins-Bruner D (2003) Free prostate-specific antigen improves prostate cancer detection in a high-risk population of men with a normal total PSA and digital rectal examination. Urology 61: 754-759.

Valeri A, Cormier L, Moineau MP, Cancel-Tassin G, Azzouzi R, Doucet L, Baschet F, Cussenot I, L'Her J, Berthon P, Mangin P, Cussenot O,

Morin JF, Fournier G (2002) Targeted screening for prostate cancer in high risk families: early onset is a significant risk factor for disease in first degree relatives. J Urol 168: 483-487.

Zhang S, Phelan CM, Zhang P, Rousseau F, Ghadirian P, Robidoux A, Foulkes W, Hamel N, McCready D, Trudeau M, Lynch H, Horsman D, De Matsuda ML, Aziz Z, Gomes M, Costa MM, Liede A, Poll A, Sun P, Narod SA (2008) Frequency of the CHEK2 1100delC mutation among women with breast cancer: an international study. Cancer Res $\mathbf{6 8}$ : 2154-2157.

Zheng SL, Sun J, Wiklund F, Smith S, Stattin P, Li G, Adami HO, Hsu FC, Zhu Y, Bälter K, Kader AK, Turner AR, Liu W, Bleecker ER, Meyers DA, Duggan D, Carpten JD, Chang BL, Isaacs WB, Xu J, Grönberg H (2008) Cumulative association of five genetic variants with prostate cancer. $N$ Engl J Med 358: 910-919. 
This work is published under the standard license to publish agreement. After 12 months the work will become freely available and the license terms will switch to a Creative Commons AttributionNonCommercial-Share Alike 3.0 Unported License.

Supplementary Information accompanies this paper on British Journal of Cancer website (http://www.nature.com/bjc)

\section{APPENDIX}

Tomasz Byrski, Paulina Sikorska-Radek, Józef Matych, Jacek Wilkosz, Waldemar Różański, Jacek Kiś, Krzysztof Bar, Piotr Słupski, Piotr Jarzemski, Piotr Bryniarski, Andrzej Paradysz, Konrad Jersak, Jerzy Niemirowicz, Michał Skrzypczyk, Jakub
Dobruch, Jerzy Świtała, Zbigniew Kwias, Andrzej Borówka, Wenancjusz Domagała, Maria Chosia, Mirosław Kordowski, Joanna Bagińska, Kazimierz Krajka, Sławomir Archimowicz, Marek Szwiec, Marcin Życzkowski, Thierry van de Wetering, Małgorzata Stawicka, Olga Haus, Hanna Janiszewska, Agnieszka Stembalska, Maria Małgorzata Sạsiadek. 